\title{
Sclerosing cholangitis with hepatic microvesicular steatosis in cystic fibrosis and chronic pancreatitis
}

\author{
I BENETT, B SALH, N Y HABOUBI, * J M BRAGANZA \\ From the University Department of Gastroenterology, Royal Infirmary, and the *Histopathology Department, \\ Withington Hospital, Manchester
}

SUMMARY The association between asymptomatic primary sclerosing cholangitis and exocrine pancreatic disease was underlined by the findings in a patient with cystic fibrosis and in another with chronic pancreatitis. In each case hepatocytes showed extensive microvesicular steatosis and studies of drug metabolism suggested hepatic enzyme induction: biliary or serum analysis, or both, disclosed raised concentrations of a lipid-based marker of free radical oxidation. These findings suggest that toxic metabolites of oxygen or other chemicals may have a role in the pathogenesis of the bile duct lesion.

The listed hepatobiliary abnormalities in cystic fibrosis include fatty liver in $15-30 \%$ of cases, biliary cirrhosis in up to $25 \%$ with portal hypertension in some $2 \%$, and gallstones in $4-12 \%$ of cases. ${ }^{\prime}$ Primary sclerosing cholangitis, as defined in standard texts, is hardly mentioned, although a report by Porta et $a l^{2}$ of six infants with cystic fibrosis showed changes that fell within the range of the recognised histological signs of the disease. ${ }^{3}$ Similar changes have been recorded in patients with chronic pancreatitis. ${ }^{45}$ The inverse association of abnormal pancreatograms, or reduced exocrine secretory capacity, or both, in patients with primary sclerosing cholangitis, has been documented by many authors. ${ }^{45}$ The overlap between the hepatobiliary abnormalities in cystic fibrosis and chronic pancreatitis may be greater still, as illustrated by the two cases reported below.

\section{Case reports}

CYSTIC FIBROSIS AND SCLEROSING CHOLANGITIS A 31 year old chartered surveyor was referred for investigation of steatorrhoea $(640 \mathrm{mmol}$ fat in three days, normal $<60 \mathrm{mmol}$ ). He was neither a smoker nor a drinker. Gross clubbing of fingers and toes was a striking clinical feature. A low para-aminobenzoic acid (PABA) ${ }^{14} \mathrm{C}$ excretion index $(0.34$, normal $>0.76)$ indicated pancreatic exocrine failure; an abnormal endoscopic pancreatogram was typical of chronic

Accepted for publication 12 January 1989 pancreatitis. The raised serum alkaline phosphatase activity $(476 \mathrm{U} / 1$, normal $<300 \mathrm{U} / \mathrm{l})$ was investigated by endoscopic retrograde cholangiography (fig 1a) and liver biopsy (fig lb): both showed the typical changes of sclerosing cholangitis. Semithin sections stained with toluidine blue as well as electron microscopic examination of the liver biopsy specimen showed microvesicular steatosis (fig lc and 1d). Special stains for $\alpha_{1}$-antitrypsin, hepatitis B surface antigen, inspissated mucin, iron and copper binding protein were negative.

The high concentration of sodium in sweat stimulated by pilocarpine (121 mmol/l), azospermia, increased lung markings on chest $x$-ray picture and a restrictive pulmonary function test profile confirmed the clinical suspicion of cystic fibrosis. The family history showed that of the patient's three brothers, one, now aged 30 , had been diagnosed as having cystic fibrosis at the age of 18. The brothers were tissue typed: HLA A 2, 9; B 15, 16 in our patient and A 2, 28; $\mathrm{B} 15$ in his affected brother.

\section{CHRONIC PANCREATITIS AND SCLEROSING} CHOLANGITIS

A 34 year old despatch clerk was referred with a three year history of recurrent pancreatitis. He drank $60-80 \mathrm{~g}$ alcohol daily between the ages of 16 and 31 when he became teetotal, but the attacks of pancreatitis continued. He had smoked 20 cigarettes a day since the age of 16. An occupational history disclosed daily exposure to diesel exhaust fumes. The diagnosis of chronic pancreatitis was confirmed by the 


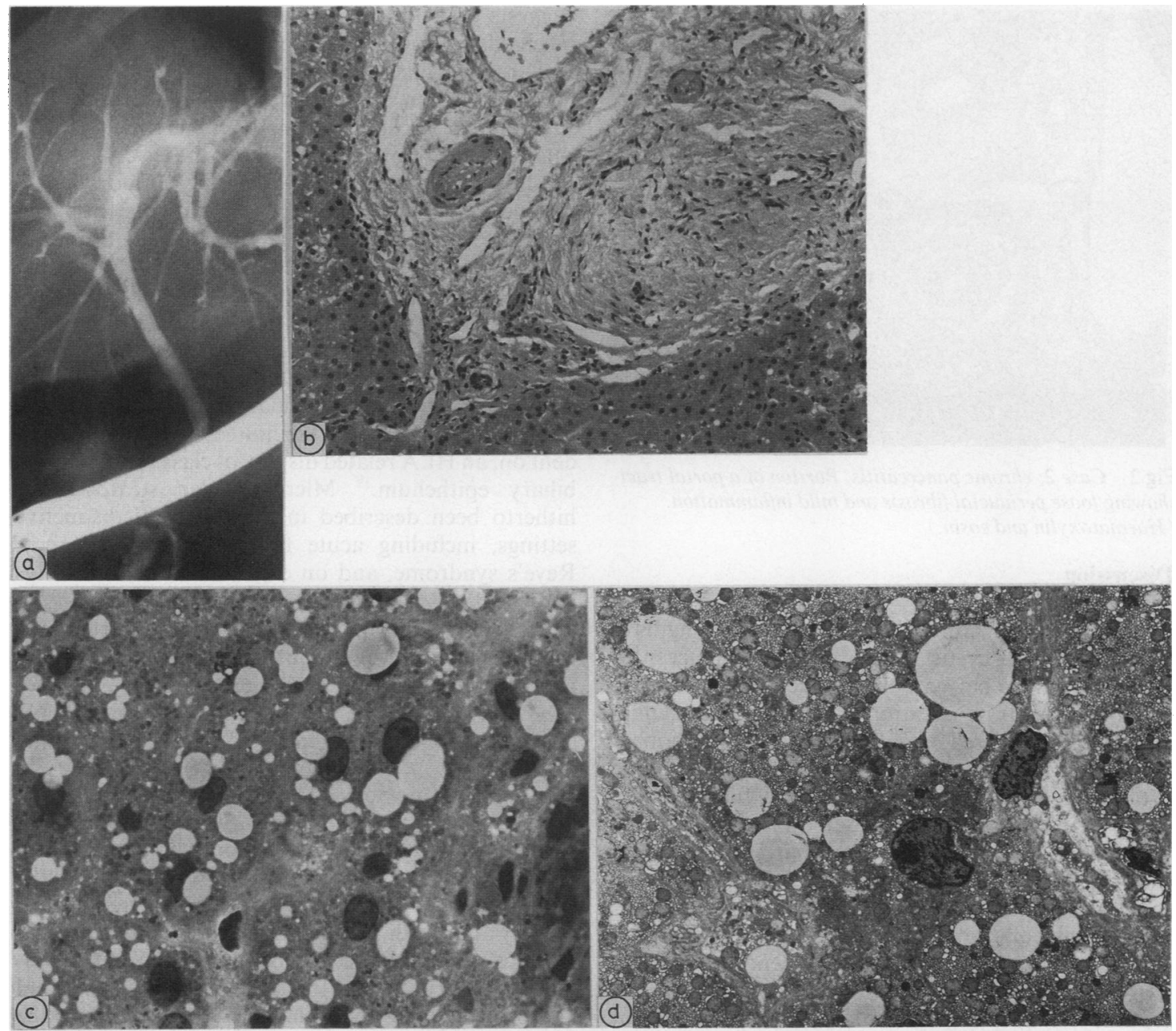

Fig 1 Case 1: cystic fibrosis. (a) Endoscopic cholangiogram showing beading in many intrahepatic bile ducts: the intrapancreatic bile duct was not constricted. (b) Portal tract showing almost complete obliteration of the bile duct by extensive periductal fibrosis. (Haematoxylin picro sirius red 0 .) (c) Extensive variable size fat droplets in hepatocytes. (Toluidine blue-stained semithin section.) (d) Electron microscopy of ultrathin section showing variable sized fat droplets.

findings of pancreatic calculi on plain abdominal $x$-ray picture, with grossly abnormal pancreatogram: pancreatic exocrine function was moderately impaired (PABA $/{ }^{14} \mathrm{C}$ index 0.64). The marginally raised serum alkaline phosphatase activity $(350 \mathrm{U} / \mathrm{l})$ was ascribed to changes which fell within the range of features of primary sclerosing cholangitis on retrograde cholangiography and percutaneous liver biopsy (fig 2): the biopsy specimen also showed micro/macrovesicular steatosis in hepatocytes and excessive amounts of lipofuscin, considering the patient's age. His tissue type was HLA A3; B22, 40.

Indirect evidence of induction of the hepatic drug metabolising enzymes glutathione S-transferase B, cytochromes $\mathbf{P 4 5 0}$, and glucuronyl transferase is afforded by an increase in the early phase disappearance constant after an intravenous injection of sulphobromophthalein (BSP $k_{i}$ ), the clearance of theophylline, and the concentration of D-glucaric acid in urine, respectively. ${ }^{6-11}$ Reference ranges for these tests and for the serum and biliary concentrations of a lipidbased marker of free radical oxidation-the 9,11 isomer $\left(9,11 \mathrm{LA}^{\prime}\right)$ of linoelic acid $\left(9,12 \mathrm{LA}^{12-13}\right)$-are given in the table, along with published data in groups of patients with cystic fibrosis and chronic pancreatitis, and the values in the subjects of this report. 


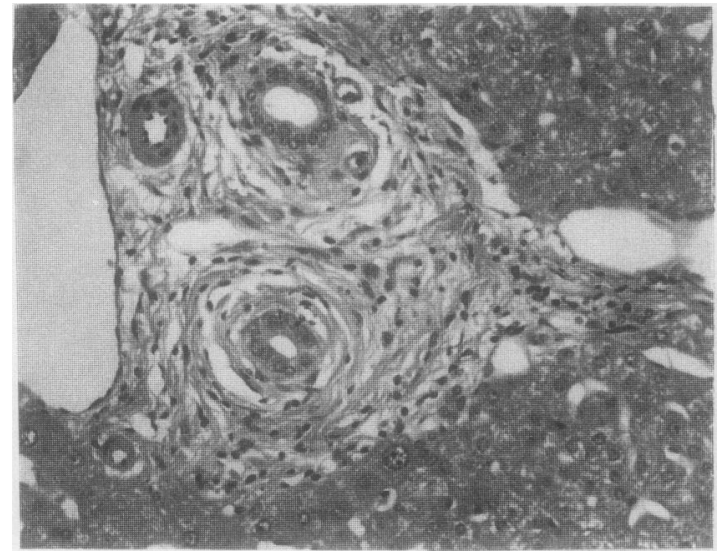

Fig 2 Case 2: chronic pancreatitis. Portion of a portal tract showing loose periductal fibrosis and mild inflammation. (Haematoxylin and eosin.)

\section{Discussion}

The finding of asymptomatic sclerosing cholangitis in the patient with cystic fibrosis extends the accepted areas of overlap between this congenital disease and acquired chronic pancreatitis, both alcoholic and nonalcoholic. ${ }^{14}$ Increased osmolality of sweat, pulmonary restrictive defects, attacks of pancreatitis, ductal protein plugs, pancreatic calculi, and tubular complexes representing dedifferentiated acini progressing to acinar effacement, are features that are shared to a varying extent between cystic fibrosis and chronic pancreatitis. Biliary cirrhosis is a recognised complication of each condition but primary sclerosing cholangitis is not. Furthermore, the coexistence of primary sclerosing cholangitis with microvesicular fat in hepatocytes, as in both patients in this report, has not been recorded in any other disease. Their concurrence suggests that both lesions are produced by the same mechanism. We propose that this involves excessive free radical activity through induction of drug metabolising enzymes and other potential routes. ${ }^{15}$

Primary sclerosing cholangitis preferentially affects small and medium sized bile ducts: the lesion has been produced inadvertently by infusing 5-fluorodeoxyuridine into the hepatic artery in patients with liver metastases, ${ }^{16}$ or experimentally by infusing a formaldehyde solution into the bile ducts of rats. ${ }^{17}$ Possession of the autoimmune haplotype HLA $A_{1} B_{8} D_{3}$ renders patients with ulcerative colitis susceptible to primary sclerosing cholangitis. ${ }^{18}$ These observations suggest that an abnormal (in amount, type, or both) biliary constituent triggers the inflammatory process, the perpetuation of which is facilitated by, but not dependent on, an HLA related display of class II antigens on biliary epithelium. ${ }^{19}$ Microvesicular steatosis has hitherto been described in different and distinctive settings, including acute fatty liver of pregnancy, Reye's syndrome, and on exposure to certain drugs and chemicals (sodium valproate, paracetamol, halogenated hydrocarbons, alcohol). It is suspected that this change, which represents disrupted microtubular transport in hepatocytes, is caused by toxic metabolites-whether oxygen free radicals, or reactive drug or chemical intermediates generated via the cytochromes P450. ${ }^{15}$

We have previously noted the coexistence of primary sclerosing cholangitis with microvesicular steatosis or excess lipofuscin, or both, in patients with chronic pancreatitis and have proposed that the lesions are caused by excessive hepatic free radical activity and the discharge into bile of reactive drug or chemical intermediates along with stable but potentially toxic products of free radical oxidation of lipid and protein. ${ }^{45}$ This hypothesis took into account the capacity of certain products to change the structure of

Table Data on three in vivo tests of hepatic enzyme induction and a lipid based marker of free radical activity

\begin{tabular}{|c|c|c|c|c|c|}
\hline & $\begin{array}{l}\text { Reference } \\
\text { ranges }\end{array}$ & $\begin{array}{l}\text { References on } \\
\text { cystic fibrosis } \\
\text { group data }\end{array}$ & Case 1 & $\begin{array}{l}\text { References on } \\
\text { chronic } \\
\text { pancreatitis } \\
\text { group } \\
\text { data }\end{array}$ & Case 2 \\
\hline $\begin{array}{l}\text { Induction markers: } \\
\text { BSP } \mathbf{k}_{\mathrm{i}} \\
\text { Theophylline clearance }(\mathrm{mg} / \mathrm{h} / \mathbf{k g})\end{array}$ & $\begin{array}{l}9 \cdot 4-15 \cdot 8^{6} \\
15-66^{8} \\
50-97^{9} \\
45-81^{10}\end{array}$ & $\underset{\uparrow}{\text { No information in adults }}{ }^{7}$ & $\begin{array}{l}20 \\
95\end{array}$ & $\uparrow^{\circ}$ & $\begin{array}{r}23 \\
189\end{array}$ \\
\hline Urinary D-glucaric acid ( $\mathrm{mmol} / \mathrm{mol}$ creatinine) & $0.41-4 \cdot 82^{11}$ & $\uparrow 10$ & $5 \cdot 50$ & $\uparrow "$ & $6 \cdot 72$ \\
\hline $\begin{array}{l}\text { Free radical oxidation products: } \\
\text { Serum } 9,11 \text { linoleic acid/ } \\
9,12 \text { linoleic acid molar ratio }(\%) \\
\text { Biliary } 9,11 \text { linoleic acid by duodenal drainage } \\
\quad \text { for } 10 \text { minutes after secretin }(\mu \mathrm{mol})\end{array}$ & $\begin{array}{l}0 \cdot 76-3 \cdot 32^{12} \\
0 \cdot 81-3 \cdot 90^{13} \\
1 \cdot 12-2 \cdot 76^{13}\end{array}$ & $\begin{array}{l}\uparrow 10 \\
\text { Duodenal aspirate too } \\
\text { viscid for analysis }\end{array}$ & 3.98 & $\uparrow^{13}$ & 5.00 \\
\hline
\end{tabular}

Arrows indicate significantly increased group values in published accounts. 
gamma globulin (and, thereby, its immunogenecity) to disturb membrane function, and to provoke chemotaxis and fibrosis. ${ }^{12}$ It also considered findings of a preliminary occupational survey in patients with chronic pancreatitis ${ }^{20}$ and data from pharmakokinetic studies $^{15}$ and biliary analysis. ${ }^{21}$ Case 2 in the present report is a typical example and, as in patients with chronic pancreatitis in general, he did not possess the autoimmune HLA haplotype. ${ }^{22}$ That haplotype is not associated with cystic fibrosis either ${ }^{23}$ Yet our patient (case 1) had unequivocal changes of primary sclerosing cholangitis while hepatic oxidant stress was suggested by the findings of microvesicular steatosis and raised serum $9,11 \mathbf{L A}^{\prime}$. The possibility that microsomal monoxygenases may contribute to oxidant stress in cystic fibrosis is suggested by published pharmakokinetic data ${ }^{810}$ and ultrastructural studies showing expansion or dilatation of the endoplasmic reticulum of hepatocytes ${ }^{24}$; while the possibility that oxidant stress may underly the basic genetic defect is suggested by observations pertaining to two other target organs-namely, nasal epithelium ${ }^{2526}$ and the exocrine pancreas. ${ }^{27}$

Finally, the two case reports indicate that both primary sclerosing cholangitis and microvesicular steatosis can be completely asymptomatic. The routine availability of endoscopic cholangiography has made this point in the context of primary sclerosing cholangitis in patients with ulcerative colitis; but it is not clear from published accounts whether microvesicular steatosis was looked for and excluded in those patients.

We thank Dr P Dyer for tissue typing our patients. We are grateful to Miss E A Wilson, Mrs J Hanbridge, and Miss M D Garner for typing the manuscript.

\section{References}

1 Park RW, Grand RJ. Gastrointestinal manifestations of cystic fibrosis. Gastroenterology 1981;81:1143-61.

2 Porta EA, Stein AA, Patterson P. Ultrastructural changes of the pancreas and liver in cystic fibrosis. Am J Clin Pathol 1964; 42:451-65.

3 MacSween RNM, Anthony P, Scheuer P. Pathology of the liver. 2nd edition. London: Churchill Livingstone, 1987.

4 Warwick F, Anderson RJL, Braganza JM. Sclerosing cholangitislike changes in pancreatic disease. Clin Radiol 1985;36:51-6.

5 Haboubi NY, Ali HH, Braganza JM. Liver histology in patients with pancreatitis: a clue to aetiology? Mt Sinai J Med 1986; 53:380-8.

6 Braganza JM. Altered clearance of sulphobromophthalein (BSP) in patients with pancreatic disease. Clin Chim Acta 1984;138: 163-73.

7 Grand RJ, Lebenthal E, Jacobson M, Kevy S, Swachman H. Predive value of BSP kinetics for early liver involvement in cystic fibrosis. Proceedings VIIth International Cystic Fibrosis Congress, Paris. Paris: Jouve, 1978:463-8.

8 Isles M, Spino M, Tabachnik E, Levison H, Thiesson J, MacLeod S. Theophylline disposition in cystic fibrosis. Am Rev Respir Dis 1983;127:417-21.

9 Acheson DWK, Rose P, Houston JB, Braganza JM. Induction of cytochromes $\mathrm{P450}$ in pancreatic disease: consequence, coincidence or cause? Clin Chim Acta 1985;151:73-84.

10 Salh B, Webb K, Braganza JM, Sandle LR. Microsomal drug metabolism in cystic fibrosis. Clin Sci 1988;74(suppl 18):1-20.

11 Sandle LR, Braganza JM. An evaluation of the low-pH enzymatic assay of urinary D-glucaric acid, and its use as a marker of enzyme induction in exocrine pancreatic disease. Clin Chim Acta 1987;162:245-56.

12 Dormandy TL. Free radical activity and diene conjugation in man. In: Poli G, Cheeseman KH, Dianzani MU, eds. Free radicals in liver injury. Oxford: IRL Press, 1985:167-74.

13 Uden S, Guyan PM, Kay P, Kay GH, Braganza JM. Heightened free radical activity in patients with pancreatitis. Clin Sci 1988;74(suppl 18):1-32.

14 Braganza JM. Cystic Fibrosis: a casualty of "detoxification"? Med Hypoth 1986;20:233-43.

15 Braganza JM. The role of the liver in exocrine pancreatic disease. Int J Pancreatol 1988;3:S19-S42.

16 Shea WJ, Demas BE, Goldberg HI, Hohn DC, Ferrell LD, Kerlan RK. Sclerosing cholangitis associated with hepatic arterial FUDL chemotherapy: radiographic-histologic correlation. Am J Radiol 1986;146:717-26.

17 Houry S, Languille O, Hugier M. Experimental sclerosing cholangitis in rat induced by formalin injection in the biliary tract. Dig Dis Sci 1986;31(suppl 10):108 S.

18 Schrumpf E, Fansa O, Førree $O$, Doblough JH, Ritland S, Thorsby E. HLA antigens and immunoregulatory $T$ cells in ulcerative colitis associated with hepatobiliary disease. Scand $J$ Gastroenterol 1982;17:187-91.

19 Chapman RW, Kelly PMA, Heryet A, Jewell DP, Fleming KA. Expression of HLA-DR antigens on bile duct epithelium in primary sclerosing cholangitis. Gut 1988;22:422-7.

20 Braganza JM, Jolley JE, Lee WR. Occupational volatile chemicals and pancreatitis: a link? Int $J$ Pancreatol 1986;1:9-20.

21 Braganza JM, Wickens D, Cawood P, Dormandy TL. Lipid peroxidation (free radical oxidation) products in bile from patients with pancreatic disease. Lancet 1983;ii:375-9.

22 Anderson RJL, Dyer P, Donnai D, Braganza JM. HLA-A and B antigens in chronic pancreatitis. Int J Pancreatol 1988;3:83-90.

23 Hennequet A, Jehanne M, Hors J, Schmid J, Schmid M, Dausset J. Muscoviscidose et marquers HLA-A et B. Proceedings VIIth International Cystic Fibrosis Congress, Paris. Paris: Jouve, 1978:243-7.

24 Dominick H Ch, von Bassenwitz DB, Arends P. Ultrastructure of the liver in cystic fibrosis. Proceedings of VIIth International Cystic Fibrosis Congress, Paris. Paris: Jouve, 1978:74-7.

25 Salh B, Webb K, Guyan PM, et al. Aberrant free radical activity in cystic fibrosis. Clin Chim Acta (in press).

26 Gavalor SM, Mezhevitch NA, Buzueva II. The ultrastuctural investigation of nasal mucosa glands in patients with mucoviscidosis. Proceedings of VIIth International Cystic Fibrosis Congress, Paris. Paris: Jouve, 1978:127-31.

27 Wallach JD, Germaise B. Cystic fibrosis: a perinatal manifestation of selenium deficiency. In: Hemphil DD, ed. Trace substances in environmental health. Columbia: University of Missouri Press, 1979:469-76.

Requests for reprints to: Dr J M Braganza, Department of Gastroenterology, Royal Infirmary, Oxford Road, Manchester M13 9WL, England. 